\title{
DISIPLIN KEILMUAN HINDU: TELAAH FILSAFAT ILMU
}

\author{
Oleh: \\ I Wayan Sukarma \\ perama.diksa@yahoo.com \\ Pascasarjana \\ Universitas Hindu Indonesia
}

Proses Review 02-14 April, Dinyatakan Lolos 16 April

\begin{abstract}
Religion comes with a variety of stucture in the human society. In this concern various views of religion have emerged. There seems to be paradox of the view between theologians and scientists, even causing a competition between religion and science. Gratefully, Friedrich Max Muller promotes The Science of Religion by looking at religion objectively. The aim is at finding the elements and the principles of the uniformity in religion based on facts, patterns, habits, rituals, and beliefs. This objective reality is also found in the activities of Hinduism, either as symptoms, phenomena, texts, or other social relations that can be analyzed ontologically, epistemologically, and axiologically. Hopefully, the scientific studies of Hinduism can contribute, both to the science and the Hindu religion.
\end{abstract}

Keywords: Hindu, philosophy, science, religion

\begin{abstract}
Abstrak
Agama tampil dengan beragam wajah dalam masyarakat manusia, karena itu muncullah berbagai pandangan tentang agama. Paradoks pandangan antara teolog dan ilmuwan, bahkan menimbulkan persaingan antara agama dan sains. Bersyukur Friedrich Max Muller mempromosikan The Science of Religion (ilmu agama), memandang agama secara objektif. Tujuannya, menemukan elemen dan prinsip yang seragam dalam agama berdasarkan fakta, pola, kebiasaan, ritual, dan kepercayaan. Realitas objektif ini, juga ditampilkan agama Hindu, baik sebagai gejala, fenomena, teks, maupun relasi sosial lainnya yang dapat ditelaah secara ontologi, epistemologi, dan aksiologi. Dengan harapan, studi ilmiah tentang Hindu dapat memberikan konstribusi, baik pada keilmuan maupun keagamaan Hindu.
\end{abstract}

Kata Kunci: Keilmuan Hindu dan Filsafat Ilmu 


\section{PENDAHULUAN}

Kebenaran agama bersifat mutlak karena berasal dari wahyu Tuhan dan sebaliknya, kebenaran ilmu bersifat nisbi karena berasal dari akal-budi manusia dalam rangka memahami realitas. Diskursus kebenaran ini mewarnai perdebatan antara ilmu dan agama yang sulit didamaikan. Ketika Federich Max Muller mengenalkan 'ilmu agama' (the science of religion) pertama kali dalam sebuah kuliah umum di Royal Institution, London (1870) berbagai reaksi bermunculan. Studi ini awalnya sempat dicurigai akan mencampuradukkan kepastian iman dengan cara kerja ilmiah yang sarat dengan eksperimen, revisi, dan perubahan. Kendatipun demikian, Muller telah memberikan batasan bahwa ilmu agama tidak menilai kebenaran iman suatu agama, tetapi hanya mengumpulkan fakta, adat istiadat, ritual, dan kepercayaan dalam suatu agama kemudian, menjelaskannya untuk membangun teori agama. Sejak itulah minat terhadap studi agama meningkat dan berkembang menjadi disiplin ilmu yang mapan dengan melibatkan berbagai disiplin ilmu lainnya, seperti sejarah, arkeologi, etnologi, psikologi, sosiologi, antropologi, mitologi, dan filologi (Pals, 2001:6-12).

Objek utama studi agama menurut Adams (Binder (Ed.), 1976:32-33) mencakup 'perilaku luar' (outward behaviour) dan 'pengalaman dalam' (inward experience); atau menurut Smith (Eliade \& Kitagawa (Ed.), 1973:35) tradisi (tradition) dan keyakinan (faith). Perilaku luar (tradisi) merupakan manifestasi agama pada ruang dan waktu, seperti ritual, ajaran, dan institusi keagamaan; sedangkan pengalaman dalam (kepercayaan) meliputi dimensi subjektif pemeluk agama, seperti penghayatan, sikap, motivasi, orientasi, dan pengalaman religius. Hanya saja Geertz (1973:89-93) tidak membedakan keduanya secara kaku, tetapi memandangnya sebagai 'realitas objektif' dalam sistem simbol. Agama melalui perantara simbolik menampakkan diri sebagai realitas kebudayaan sekaligus kejiwaan. Selain mengacu pada ketetapan budaya, juga simbol-simbol agama merefleksikan kepercayaan, motivasi, emosi, kognitif, dan sikap pemelukagama. Sistemsimbolmempertahankan keteraturan sistem yang ditransmisikan dalam sejarah yang meninggalkan jejak dari waktu ke waktu.

Agama sebagai realitas objektif yang menyejarah menyediakan peluang bagi studistudi agama untuk mengungkap berbagai pemikiran dan praktik keagamaan dari periode kuno hingga kini melalui berbagai pendekatan. Adams (Binder (Eds.), 1976:33) merekomendasikan dua pendekatan umum dalam studi agama yang berada pada satu garis kontinum, yaitu normatif dan deskriptif. Pendekatan normatif lebih dijiwai motivasi dan tujuan keagamaan yang melahirkan beberapa varian pendekatan lainnya, seperti pendekatan misionaris, apologetik, dan irenic (simpati). Sebaliknya, pendekatan deskriptif lebih dijiwai motivasi intelektual dan akademis sehingga lebih terbuka dengan berbagai cara kerja lintasdisiplin ilmu, seperti psikologi, sosiologi, antropologi, sejarah, dan filologi. Berbeda dengan itu, juga Connoly (Ed.) (2001:3) menyoroti studi agama dari segi kedudukan peneliti dalam studi yang dilakukan, yaitu pemeluk agama (insider) dan bukan pemeluk agama (outsider). Seorang insider lebih berpotensi memasukkan pengetahuan dan cara pandang agamanya dalam studi yang dilakukan dibandingkan dengan outsider. Pandangan ini tidak bermaksud mengatakan bahwa peneliti yang a-religius akan lebih objektif, tetapi menekankan pentingnya memasang jarak kritis dengan objek kajian.

Aneka pendekatan dalam studi agama secara prinsipil bertujuan membangun teori agama atau setidak-tidaknya mengembangkan konsep dan proposisi dalam studi yang dilakukan. Mengingat objek studi agama mencakup semua realitas objektif yang terdapat pada setiap agama sehingga niscaya untuk membangun dan mengembangkan teori-teori agama tertentu termasuk Hindu. Apalagi realitas keagamaan Hindu, selain berdimensi keyakinan (faith), juga berdimensi tradisi (tradition) sebagai representasi kualitas intelektual dan peradaban pemeluknya pada berbagai zaman. Faktanya, umat Hindu tidak hanya bertumpu pada satu teks tunggal (Weda), tetapi juga teks-teks lain yang menandai kualitas intelektual para pemikir Hindu yang kemudian, membangun struktur 
hirarkis teks keagamaan. Selain itu, juga praktik keagamaan Hindu bergerak dinamis seiring dengan perubahan sosiokultural masyarakatnya. Oleh karena itu, studi Hindu penting dilakukan untuk mengungkap dan menyingkap keanekaragaman dan jenis-jenis pengetahuan Hinduistik yang bermanfaat, baik bagi dunia akademis maupun praktis. Akan tetapi, penting dipahami bahwa interaksi ilmu dan agama tidak selalu berjalan pada garis kontinum yang sama sehingga disiplin keilmuan Hindu sebagai sebuah disiplin ilmiah perlu ditelaah lebih luas dan mendalam berdasarkan filsafat ilmu.

\section{PEMBAHASAN}

\subsection{Mendisiplinkan Keilmuan Hindu}

Ilmu adalah pengetahuan yang rasional dan didukung bukti empiris. Ilmu berisi teori dan teori adalah pendapat berlasan (Tafsir, 2006:6). Sementara itu, Gie (2000:88-90) mengartikan ilmu sebagai sekumpulan aktivitas manusia secara metodis untuk mendapatkan pengetahuan yang sistematis. Artinya, ilmu melibatkan interaksi tiga aspek sebagai kesatuan, yaitu aktivitas, metode, dan pengetahuan. Aspek pertama menekankan ilmu sebagai proses, yakni aktivitas penelitian; aspek kedua menekankan ilmu sebagai prosedur, yakni penerapan metode ilmiah; dan aspek ketiga menekankan ilmu sebagai produk, yakni pengetahuan yang sistematis. Ketiga aspek ini mesti dan harus hadir dalam setiap kegiatan keilmuan sehingga pengetahuan yang dihasilkan layak disebut pengetahuan ilmiah, ilmu pengetahuan, sains. Dengan begitu, ilmu agama merupakan aktivitas, metode, dan pengetahuan yang sistematis tentang agama. Dalam hal ini, agama menjadi objek ilmu atau studi yang dapat dipandang sebagai gejala, fenomena, dan teks keagamaan yang dapat disingkap (diproduksi) atau diungkap (didemonstrasikan) dengan beraneka pendekatan.

Gejala merupakan segala sesuatu yang dapat ditangkap indera manusia, baik nominal, interval, maupun ordinal atau mendekati terminologi 'noumena' menurut Kant, yaitu sesuatu dalam dirinya sendiri (Hadiwijono, 1980:69). Misalnya, badan panas adalah gejala penyakit sehingga untuk mengetahui penyakitnya dapat dilakukan dengan mengukur dan meneliti panas badan tersebut. Dengan pola serupa, juga gejala keagamaan dapat dipahami sebagai fakta objektif sehingga pendekatan positivistik dapat diterapkan dalam studi-studi agama misalnya, analisis sistem, struktural, dan fungsional. Agama juga dapat dipandang sebagai fenomena, yaitu sesuatu yang menampakkan diri dalam pengalaman subjek. Menurut Husserl (Adian, 2002:64), fenomena bukanlah sesuatu yang faktual karena ia tidak berurusan langsung dengan eksistensi dan non-eksistensi. Misalnya, sebuah lagu disebut melankolis bukan karena lirik dan musiknya, melainkan ketika mampu menimbulkan suasana kesedihan orang yang mendengarkannya. Begitu pula fenomena keagamaan yang menampakkan diri dalam aktivitas sakral tidak terletak pada bentuk aktivitas itu, tetapi pada kesadaran pelakunya dan upaya subjek lain memahaminya. Oleh karena itu, agama sebagai fenomena relevan didekati dengan fenomenologi, yakni memandang agama sebagai realitas kesadaran danlebihmenekankan metodeintersubjektivitas. Agama juga menampakkan diri dalam bentuk teks, baik tertulis maupun lisan sehingga pendekatan hermeneutik relevan diterapkan untuk mengetahui dan memahaminya. Studistudi agama kontemporer, juga menerapkan pendekatan teori kritis untuk memahami relasi agama dengan berbagai bidang kehidupan, seperti sosial, kultural, ekonomi, politik, modernisasi, dan globalisasi.

Artinya, agama tidak hanya berhubungan dengan 'dunia lain' yang abstrak dan transenden, tetapi juga melibatkan masalah-masalah kehidupan sehari-hari (Nottingham, 2002:3). Agama sebagai realitas objektif memang terdiri atas badan ajaran (pasal-pasal iman), peraturan (moral), dan upacara-upacara (ritual) yang diyakini bersumber dari wahyu Ilahi yang ditanggapi manusia melalui pengungkapan lahiriah melalui simbol-simbol dan praktik keagamaan serta batiniah melalui ketaatan dan emosi keagamaan (Bakker, 1984:48). Oleh karena ilmu agama memandang agama sebagai realitas objektif sehingga teks agama dan konteks keberagamaan merupakan materi pokok (subject matter) ilmu agama yang secara spesifik juga dapat diterapkan dalam kajian- 
kajian Hinduistik.

Teks keagamaan Hindu secara otoritatif berpusat pada Catur Veda Samhita yang diyakini sebagai sruti (yang didengar, wahyu). Weda bermaterikan pengetahuan, baik pengetahuan keagamaan (paravidya) maupun pengetahuan umum atau praksis (aparavidya). Ajaran keagamaan Weda (paravidya) secara umum dapat diklasifikasi ke dalam aspek ritual (karma kanda) yang termaktub dalam kitab-kitab brahmana, aspek pengetahuan-kontemplatif (jnana kanda) dalam teks-teks upanisad, dan aspek etik-spiritual (upasana kanda) dalam teks-teks aranyaka. Sementara itu, pengetahuan umum atau praksis (aparavidya) meliputi berbagai jenis ilmu yang tidak jauh berbeda dengan tradisi ilmu modern, seperti geografi, astronomi, ekonomi, matematika, ilmu alam, dan hukum. Secara spesifik kaum intelektual Hindu Kuno mengembangkan cabang-cabang pengetahuan khusus yang dituangkan dalam teks-teks smerti, baik vedangga maupun upaveda. Risalah pengetahuan vedangga mencakup siksha (ilmu fonetik), chanda (irama), vyakarana (tata bahasa), jyotisa (ilmu perbintangan), kalpa (waktu), dan niruktha (etimologi) sebagai ilmu membaca dan memahami isi Weda. Upaveda atau Weda minor mencakup pengetahuan tentang hukum (dharmasastra), politik dan ketatanegaraan (arthasastra dan nitisastra), seksualitas (kamasastra), seni musik dan tari (gandharvaveda), seni drama (natyasastra), arsitektur (sthapathyaveda), ilmu pengobatan (ayurveda), ilmu memanah (dhanurveda), epik historis (itihasa), mitologi (purana), dan filsafat (darsana) (Machwe, 2000; Saraswati, 2009).

Perkembangan keilmuan Hindu seperti di atas menunjukkan tradisi berpikir masyarakat India Kuno, baik dalam keagamaan maupun kebudayaan. Mengingat teks-teks tersebut ditulis dalam kurun waktu berbeda sebagai respons intelektual atas perubahan yang terjadi. Para pemikir India Kuno sesungguhnya juga telah melibatkan diri dalam perdebatan serius tentang ilmu dan filsafat, bahkan membuat klasifikasi ilmu pengetahuan dan seni. Secara tradisi, widya (ilmu pengetahuan) berjumlah 22, sedangkan kala (seni) berjumlah 64. Maharsi Sukra menyatakan, hanya Artha (politik dan ekonomi sebagai kesatuan) yang disebut ilmu. Maharsi Manu menyebutkan tiga cabang ilmu, yakni Trayiveda, Vartta (ekonomi), dan Dandaniti (hukum dan politik). Maharsi Brihaspati menyatakan hanya Vartta dan Dandaniti yang tergolong kategori ilmu. Maharsi Usana menyebutkan hanya dandaniti (politik) sebagai ilmu. Kemudian, Maharsi Kautilya menyebutkan empat jenis ilmu, yaitu Trayiveda, Anviksakhi (filsafat), Vartta (ekonomi), dan Dandaniti (hukum dan politik) (Sen, 1926:12). Akan tetapi, ketika filsafat nastika menjadi bagian dari pemikiran India Kuno, maka perlu dibedakan antara pemikiran Hindu dan India.

Dalam konteks keilmuan dapat dimengerti bahwa tradisi pemikiran Hindu telah berkembang demikian pesat dalam kurun waktu yang hampir bersamaan dengan perkembangan keilmuan dan filsafat Barat (Yunani dan Romawi) sekitar abad ke-6 SM hingga awal masehi. Meskipun demikian, pemikiran Timur (India dan wilayah oriental lainnya) cenderung tidak pernah memisahkan ilmu, filsafat, dan agama secara tegas. Berbeda dengan pemikiran Barat (oksidental) yang sejak abad pencerahan telah memisahkan fisafat, ilmu, dan agama sebagai cabang pengetahuan yang otonom (Radhakrishnan, 2003). Hegemoni pemikiran Barat dalam perkembangan ilmu pengetahuan dan teknologi seiring dengan modernisasi, juga memberikan tantangan tersendiri bagi pengetahuan oriental karena keabsahan jenis, ragam, dan metode ilmu sepenuhnya ditentukan oleh Barat.

Menyikapi kondisi tersebut menjadi 'mustahil' mengembangkan keilmuan Hindu tanpa melibatkan keilmuan Barat. Tembok hegemoni yang terlalu kuat untuk ditembus ini memang menyisakan peluang bagi pengembangan keilmuan Hindu, jika dan hanya jika, mampu mengadopsi metode ilmiah dengan menerapkan pendekatan, paradigma, perspektif, dan teori-teori yang telah dimapankan Dunia Barat. Di sinilah letak penting dan relevansi upaya pendisiplinan keilmuan Hindu dengan memeriksa keabsahan ilmu yang hendak dibangun berdasarkan prinsip-prinsip filsafat ilmu. Dalam hal ini, kedudukan keilmuan Hindu secara ontologis, epistemologis, dan aksiologis merupakan syarat mutlak yang harus dipenuhi 
agar berterima dalam panggung akademis. Dengan demikian, ajaran-ajaran Hindu yang terkandung dalam teks-teks keagamaan dapat digali (diproduksi dan didemonstrasikan), dijelaskan, dan disosialisasikan dalam pentas akademis dunia. Pada akhirnya menemukan manfaatnya dalam rangka mengatasi berbagai masalah kehidupan yang membutuhkan kerja sama antara agama dengan sains.

\subsection{Keilmuan Hindu dalam Telaah Filsafat Ilmu}

Filsafat ilmu adalah landasan filosofis yang harus selalu hadir dalam setiap kegiatan keilmuan (Muslih, 2004:5). Filsafat ilmu merupakan penyelidikan kritis dan analitis terhadap setiap bidang ilmu terutama pada elemen-elemen yang menjadi tiang penyangga eksistensinya, yaitu ontologi, epistemologi, dan aksiologi (Siswomihardjo, 2003:12). Selain menentukan derajat keabsahan ilmu, juga filsafat ilmu menegaskan posisi ilmu dalam kerangka umum keilmuan. Kedudukan filsafat ilmu dalam konteks ilmu pengetahuan menjadi demikian sentralterutamaketika pengembangan ilmu terus bergerak ke arah yang semakin spesifik. Oleh karena itu, telaah filsafat ilmu terhadap keilmuan Hindu diarahkan pada aspek ontologis, epistemologis, dan aksiologis.

Telaah ontologis terutama diarahkan untuk memeriksa hakikat objek kajian keilmuan Hindu, baik material maupun formalnya; klasifikasi keilmuan Hindu dalam kerangka ilmu; dan karakteristik keilmuan Hindu. Pertama, objek material keilmuan Hindu meliputi seluruh gejala, fenomena, dan teks keagamaan Hindu. Sementara itu, objek formal adalah perspektif, kerangka teoretis, atau disiplin ilmu yang digunakan sebagai alat untuk menganalisisnya (Romdon, 1996:1-6). Keilmuan Hindu dapat menggunakan berbagai disiplin ilmu sebagai objek formalnya, tetapi tergantung pada perhatian dan pengetahuan yang hendak dibangun dan dikembangkan peneliti, seperti sejarah, arkeologi, psikologi, teologi, sosiologi, antropologi, filologi, fenomenologi, dan linguistik. Kedua, agama merupakan emanasi dari kepercayaan manusia yang subjektif (ide) ke realitas objektif (materi) sehingga Wach (Ghazali, 2000:19) menegaskan bahwa studi agama bertujuan untuk memahami (to understand), bukan sekedar mengetahui (to know). Hal ini menegaskan bahwa keilmuan Hindu lebih menunjukkan kecenderungan ideosentris dan interpretatif dibandingkan nomotetis dan positivistik sehingga lebih tepat diklasifikasikan sebagai ilmu sosial dan humaniora. Ketiga, karakteristik keilmuan Hindu lebih mengapresiasi sisi-sisi humaniora karena agama, baik dalam teks dan konteksnya ditujukan kepada manusia dalam menjalani kehidupan rohani dan sosiokulturalnya. Studi Hindu diarahkan untuk meneliti agama sebagai karakter khas manusiawi (homo religious), baik kepercayaan, penghayatan, pengalaman, orientasi, sikap, perilaku, maupun pengamalan keagamaan.

Sementara itu, epistemologi adalah filsafat atau teori tentang pengetahuan yang memusatkan pembahasannya pada sumber, struktur, sarana, metode, dan keabsahan pengetahuan (Wahyudi, 2003:32). Epistemologi memeriksa kebenaran dan keabsahan pengetahuan yang diperoleh suatu ilmu. Cabang ini mengkaji secara kritis dan analitis hubungan antara objek dengan daya tangkap manusia, seperti berpikir, mengindera, dan merasa; proses untuk mendapatkan pengetahuan yang benar; sumber atau alat yang digunakan untuk memperoleh pengetahuan; kesadaran dan metode; validitas pengetahuan; dan kebenaran pengetahuan (Siswomihardjo, 2003:12). Serupa dengan epistemologi, juga filsafat Hindu (Darsana) pada hakikatnya membicarakan aturan dan prosedur kostruksi pengetahuan dan validitasnya sebagai upaya serius dan sungguh-sunguh mencapai kebenaran. Misalnya Nyaya secara krtitis dan analitis mengupayakan kebenaran dengan pikiran dan indra, yakni pengetahuan yang rasional dan empiris. Begitu juga Waisesika mengukuhkan validitas pengetahuan terdiri atas tujuh kategori entitas, yaitu substansi, kualitas, aktivitas, sifat umum, sifat perorangan, peletakan, dan ketiadaan.

Epistemologi juga bekerjasama dengan logika untuk memeriksa cara-cara analisis dan penyimpulan kebenaran beserta metodologi dalam rangka menganalisis metode yang digunakan untuk mendapatkan kebenaran. Analisis dan penyimpulan ini serupa dengan 
upaya Nyaya membangun pengetahuan dan menegakkan kebenaran melalui pengamatan, penyimpulan, pembandingan, dan kesaksian. Epistemologi juga berhubungan erat dengan ontologi karena landasan ontologis memengaruhi sarana yang akan digunakan ilmu. Telah disinggung sebelumnya bahwa objek material menentukan pendekatan yang digunakan, seperti gejala didekati secara positivistik, fenomena dengan fenomenologi, teks dengan hermeneutik, dan interelasi agama dalam teks sosial dikaji dengan pendekatan teori kritis. Setiap pendekatan, juga mengkosntruksi paradigma keilmuan yang khas. Ritzer (2003:3-7) mendefinisikan paradigma adalah pandangan mendasar suatu disiplin ilmu tentang apa yang menjadi pokok persoalan (subject matter) yang mesti dipelajari; merumuskan apa yang harus dipelajari, persoalan apa yang mesti dijawab, cara menjawabnya, serta aturan-aturan yang harus diikuti untuk menganalisis informasi yang dikumpulkan untuk menjawab persoalanpersoalan tersebut. Dengan kata lain, paradigma menentukan metode yang diterapkan ilmu dalam menemukan kebenaran ilmiah.

Kemudian, aksiologi ilmu pada prinsipnya mengkaji manfaat dan kegunaan ilmu bagi kehidupan atau nilai teoretis dan praktis ilmu. Mengingat ilmu lahir dari kebutuhan, kepentingan, dan keperluan manusia, baik sekadar memuaskan ego intelektual maupun tujuan praksis kehidupan. Dengan demikian, ilmu menjangkau kebenaran pragmatis, seperti memiliki kegunaan (utility), dapat dikerjakan (workability), memiliki akibat atau pengaruh memuaskan (satisfactory consequencies) (Titus, 1987:241). Artinya, ilmu haruslah bermanfaat, baik secara teoretis maupun praktis misalnya, sebagai alat eksplanasi, alat prediksi, dan alat memecahkan masalah kehidupan (Tafsir, 2006:37-41).

Berkenaan dengan aksiologi ilmu, Habermas (Ghozali, dkk., 2005:124-125) beranggapan bahwa ilmu tidak mungkin bebas nilai karena setiap ilmu lahir selalu didahului kebutuhan dan kepentingan-kepentingan. Dia pun membedakan tiga jenis ilmu dengan kepentingannya masing-masing, yaitu (1) ilmu yang bekerja secara empiris-analitis untuk menyelidiki gejala-gejala alam secara empiris dan menyajikan hasil penyelidikan untuk kepentingan manusia misalnya, teknologi; (2) ilmu yang tidak menghasilkan sesuatu, kecuali berusaha memahami hubungan manusia dengan sesamanya dan memperlancar hubungan sosial, seperti studi historishermeneutik; dan (3) ilmu yang ketiga adalah teori kritis yang bertujuan membongkar penindasan dan mendewasakan manusia pada otonomi dirinya sendiri. Ini berarti, pengembangan keilmun Hindu diarahkan untuk mengembangkan pengetahuanyang bermanfaat, baik teoretis maupun praktis. Misalnya, ayurveda bermanfaat mengembangkan pemikiran sosial yang lebih mencerahkan kehidupan umat manusia dan mengembangkan nilai-nilai kemanusiaan dalam membina hubungan eksistensial Tuhan-manusia-alam.

Telaah filsafat ilmu tersebut barangkali hanya relevan untuk mengetahui dan memahami aparawidya, pengetahuan eksoteris yang tercakup dalam kebudayaan. Sementara itu, untuk mengetahui dan memahami parawidya, pengetahuan esoteris, pengetahuan religius dan spiritual yang tercakup dalam agama membutuhkan telaah mistik. Hal ini, sebagaimana penjelasan Tafsir (2006:111) bahwa mistik berkaitan dengan agama. Agama berkaitan dengan mistik karena pada hakikatnya mistik adalah pengetahuan tentang Tuhan yang diperoleh melalui laku spiritual, bukan dengan indra dan rasio. Artinya, pengetahuan mistik tidak dapat dipahami dengan akal dan nalar, baik melalui relasi 'jika-maka', 'karena-sehingga', maupun 'lebih baik-daripada'. Meskipun kadangkadang mempunyai bukti empiris, tetapi pengetahuan mistik dan pengetahuan bersifat mistik karena asbtrak-supra-rasional sehingga lebih banyak tidak mempunyai bukti empiris. Berdasarkan sifatnya, pengetahuan mistik dibedakan menjadi pengetahuan mistik biasa (tanpa kekuatan) dan pengetahuan mistik magis (dengan kekuatan dan tujuan tertentu). Mistik magis dibedakan menjadi mistik magis putih dan mistik magis hitam. Mistik magis putih berasal dari agama dan bersandar pada Tuhan, sedangkan mistik magis hitam berasal dari luar agama dan bersandar pada alam dan roh (makhluk halus). Hitam atau putih suatu 
pengetahuan mistik-magis dapat dinilai berdasarkan pada skala kebenaran dan standar kebaikan, baik ontologi, epistemologi, maupun aksiologi.

Objek pengetahuan mistik dalam pandangan Tafsir (2006) adalah objek yang abstrak-suprarasional - objek yang di luar empiris (objek sains) dan di luar abstrak-rasional (objek filsafat) misalnya, Tuhan, Jiwa, Surga, Neraka, dan alam gaib lainnya. Termasuk objek abstraksuper-rasional dan abstrak-super-natural yang hanya dapat diketahui melalui pengetahuan mistik misalnya, Leak. Berbeda dengan pengetahuan mistik putih yang tergantung dan bersandar pada kekuatan ilahi, pengetahuan mistik hitam menimbulkan kekuatan-magis, baik bersumber dari alam maupun roh (makhluk halus) sehingga menimbulkan femomena yang tidak masuk akal, irasional. Misalnya, ahli sihir memiliki kekuatan-magis-mental, dukun memiliki kekuatan-magis-benda, dan pesulap memiliki kekuatan-magis-imajinasi. Begitulah, objek yang asbtrak-super-rasional dan supernatural dapat diketahui dengan pengetahuan mistik.

Cara memperoleh pengetahuan mistik menurut Tafsir (2006), bukan dengan metode sains yang rasional-empiris ataupun metode filsafat yang abstrak-rasional, melainkan dengan hati atau rasa atau Immanuel Kant menyebutnya melalui moral: jalan supra-rasional. Jalan ini berupa pelatihan batin, seperti sistem SankhyaYoga dan pendidikan Upanisad. Kebenaran pengetahuan mistik diukur dengan berbagai skala ukuran dan dinilai dengan berbagai standar penilaian. Jika berasal dari Tuhan, maka ukuran dan penilaiannya adalah kitab suci, Weda. Misalnya, apabila Siwatattwa menyatakan bahwa Bathara Siwa adalah pelebur, maka teks itulah bukti kebenaran. Mempercayai kebenaran Bhatara Siwa tersebut menunjukkan, kebenaran pengetahua mistik adalah kepercayaan - seperti kepercayaan pada Panca Sraddha. Kadangkala kebenaran pengetahuan mistik terbukti secara empiris misalnya, orang dapat dengan leluasa mendemontrasikan kekebalan badannya di depan orang banyak bahwa dia tidak luka ditusuk dengan pisau atau pedang atau tidak terbakar api. Dalam hal ini, hubungan sebabakibat yang deduktif tidak dapat menjelaskan kekebalan karena bersifat mistik.

Kegunaan pengetahuan mistik hanya diketahui oleh para pemiliknya karena pengetahuan mistik bersifat subektif. Misalnya, dapat ditanyakan kepada sulinggih, pemangku, dasaran, dan balian. Barangkali secara kasat mata dapat diketahui bahwa pengetahuan mistik-biasa digunakan untuk memperkuat keimanan, mistik-putih untuk kebaikan, dan mistik-hitam untuk kejahatan. Bagi kaum spiritual pengetahuan mistik-biasa dapat menenteramkan jiwa, bahkan menemukan kenikmatan luar biasa ketika bertemu dengan Tuhan. Pengetahuan mereka seringkali menyelesaikan masalah yang tidak dapat diselesaikan dengan pengetahuan ilmiah, sains dan filsafat. Seperti teladan para Yogin, Sanyasin, Rsi, dan orang-orang suci lainnya yang sudah mengatasi realitas dan takdirnya sendiri. Dengan pancaran ketuhanannya dapat menundukkan kondisi alam, situasi sosial, dan suasana budaya.

\section{PENUTUP}

Sederhananya, disiplin keilmuan Hindu dalam telaah filsafat ilmu berkenaan dengan 'ilmu pengetahuan yang logis-empiris' tentang 'agama Hindu yang empiris', baik gejala, fenomena, teks, maupun relasi sosial lainnya yang biasanya dibedakan dengan pengetahuan filosofis Hindu 'yang hanya logis (rasional dan supra-rasional)' tentang 'agama Hindu yang abstrak-logis'. Disiplin keilmuan Hindu dalam pentas akademis patut diapresiasi dan perlu dirumuskan lebih serius dan sungguh-sungguh. Bukan hanya sekadar kebanggaan profetik bahwa Hindu memiliki berbagai ilmu pengetahuan dengan beragam teori dan perspektif. Melainkan yang lebih penting, antara lain keilmuan Hindu dapat memberikan dan menjadi solusi bagi permasalahan hidup yang tidak dapat diatasi sains lainnya. Apalagi dalam pandangan Hindu bahwa ilmu mesti dan harus terikat nilai karena ilmu merupakan bagian dari kehidupan yang tidak bebas nilai.

Menghadirkan keilmuan Hindu yang berterima dalam panggung akademis memang memerlukan pendisiplinan berdasarkan kaidah filsafat ilmu, baik ontologi, epistemologi, 
maupun aksiologi. Seperti objek studi, pendekatan, paradigma, teori, metode, dan manfaat keilmuan Hindu yang mencerminkan disiplin ilmiah yang mapan. Apalagi agama Hindu tidak hanya berkenaan dengan pengetahuan esoteris, batiniah, tetapi juga pengetahuan eksoteris, lahiriah. Pengembangan pengetahuan, baik eksoteris maupun esoteris memang menuntut pendisiplinan berdasarkan standar ilmiah seiring dengan kebutuhan intelektual umat. Dengan demikian, pengembangan kajian multidisipliner dalam studi Hindu menemukan relevansi dan signifikansinya, baik bagi agama maupun ilmu.

\section{DAFTAR PUSTAKA}

Adian, Donny Grahal. 2002. Pilar-Pilar Filsafat Kontemporer. Yogyakarta. Jalasutra.

Bakker, J.W.M. 1984. Filsafat Kebudayaan. Yogyakarta: Kanisius.

Binder, Leonard (Eds). 1976. The Study of Middle East: Research and Schoolarship in the Humanities and the Social Scienties. New York: John Willey \& Sons.

Carthy, Arthur Mc. 2007. Kritik Ideologi Jurgen Hubermas. Yogyakarta: Narasi.

Connoly, Peter (Ed.). 2001. Aneka Pendekatan Studi Agama. Yogyakarta: LkiS.

Geertz, Clifford. 1972. The Intepretation of Culture. New York: Basic Books Inc.

Ghazali, Adeng Muchtar. 2000. Ilmu Perbandingan Agama. Bandung: Pustaka Setia.

Ghozali, Bachri, dkk. 2005. Filsafat Ilmu. Yogyakarta: Pokja Akademik UIN Sunan Kalijaga.

Gie, The Liang. 2000. Pengantar Filsafat Ilmu. Yogyakarta: Liberty.

Hadiwijono, Harun. 1980. Sari Sejarah Filsafat Barat I. Yogyakarta: Kanisius.

Machwe, Prabakhar. 2000. Kontribusi Hindu Terhadap Pengetahuan dan Peradaban. Denpasar: Widya Dharma.

Muslih, Mohammad. 2005. Filsafat Ilmu: Kajian Atas Dasar Paradigma dan Kerangka Teori Ilmu Pengetahuan. Yogyakarta: Belukar.

Nottingham, Elizabeth K. 2002. Agama dan Masyarakat Suatu Pengantar Sosiologi Agama. Jakarta: RajaGrafindo Persada.

Pals, Daniel L. 2001. Seven Theories of Religion: Dari Animisme E.B. Tylor, Materialisme Karl Marx, hingga Antropologi Budaya C. Geertz. Yogyakarta: Qalam.

Radhakrishnan, S. 2003. Agama-agama Timur dan Pemikiran Barat. Denpasar: Program Magister Ilmu Agama dan Kebudayaan Unhi Denpasar bekerjasama dengan Penerbit Widya Dharma.

Romdon. 1996. Metodologi Ilmu Perbandingan Agama. Jakarta: RajaGrafindo Persada.

Saraswati, Sri Chandrasekharendra. 2009. Peta Jalan Veda. Jakarta: Media Hindu.

Sen, Ajit Kumar. 1926. Hindu Political Thought. Delhi: Gian Publishing House.

Siswomihardjo, Koento Wibisono, dkk. 2003. "Ilmu Pengetahuan Sebuah Sketsa Umum Mengenai Kelahiran dan Perkembangannya sebagai Pengantar untuk Memahami Filsafat Ilmu", dalam buku Filsafat Ilmu. Tim Dosen Filsafat Ilmu Fakultas Filsafat UGM. Yogyakarta: Liberty.

Tafsir, Ahmad. 2006. Filsafat Ilmu: Mengurai Ontologi, Epistemologi, dan Aksiologi Pengetahuan, Bandung: Remaja Rosdakarya.

Titus, Harold. 1987. Living Issues in Phylosophy: Persoalan-persoalan Filsafat. Terjemahan H.M. Rasyidi. Jakarta: Bulan Bintang.

Wahyudi, Imam. 2003. "Ruang Lingkup dan Kedudukan Filsafat Ilmu”, dalam buku Filsafat Ilmu. Tim Dosen Filsafat Ilmu Fakultas Filsafat UGM. Yogyakarta: Liberty. 